\title{
Measuring horizontal governance: a review of public consultation by the Northern Ireland government between 2000 and 2004
}

\author{
Michael Murray, G. Honor Fagan and Paul McCusker
}

This article examines the use of public consultation by the Northern Ireland central government between the years of 2000 and 2004. Key findings suggest a general enthusiasm for its use by government and citizens, despite the identification of challenges including lack of resources as well as 'consultation fatigue'. In addition, divergences exist between the aims and expectations of administrators and those of citizens and the community and voluntary sector on the contentious issue of what should constitute 'participation'. Reflecting a key debate in the literature on whether the use of mechanisms such as public consultation signals the emergence of autonomous, horizontal networks of governance, it is argued here that instead, the way in which public consultation was used indicates a continuance of centralised, hierarchical government.

\section{Introduction}

Qver the last number of decades, public consultation has become a vital instrument ir public administration and governance. For government and local authorities, it is a valued tool in ascertaining the efficiency of service provision, the targeting of policy, as well as gathering citizens' views on potentially difficult policy decisions. At the same time, consultation holds the promise of greater participation in decision miaking for citizens, signalling a shift from hierarchy to 'heterarchy' with the emergence of 'horizontal modes' of policy making (Smismans, 2006: 4). Northern Ireland is no exception here, especially when considering the impetus of the equality mainstreaming of legislation, where public consultation is a salient feature of day-today administration. This article examines recent consultation practices employed by Northern Ireland government departments. Drawing on an extensive survey of all 12 departmental consultation activities between 2000 and 2004, as well as interviews with representatives from government departments, the Equality Commission for Northern Ireland and representatives from the community and voluntary sector, the findings reported here offer a unique insight into the prevalence of different consultation techniques, and their impact in terms of benefits and challenges, for both administrators and participants.

While this article is primarily concerned with contributing to a greater understanding of the effect of public consultation, it is hoped that the findings presented here will also add to existing empirical studies on governance in a broader context. Currently, there exists a relative poverty of such data in the area (Stoker 1998; Jordan et al, 2005: 477), to the extent that Andersen and Loftager (2005: 3) argue that the 'empirical prevalence' of governance 'is still disputed'. Moreover, Jordan et al (2005: 477) identify a need to move beyond a concentration on theorising and 
introduce more research-based work for consideration. While there has been some notable exceptions to this, ${ }^{1}$ a pressing need for more empirically based studies is underlined not least because of the contentious nature of almost every aspect of governance at the conceptual level. For instance, while an orthodoxy has slowly emerged that advocates network governance as a clear indicator of 'governance without government' (Rhodes, 1996, 2000), much research suggests that the reality is a little less clear cut, particularly when it comes to accurately positioning the role of government in such networks. For instance, in looking at the deployment of 'new environmental policy instruments' in the European Union (EU) and seven member countries, Jordan et al (2005) conclude that governance processes 'co-exist' with government rather than replace it, while in a review of research from the Economic and Social Research Council's (ESRC) Democracy and Participation Programme, Newman et al (2004) conclude that serious constraints appear to be applied to 'collaborative governance' by administrative structures and processes.

One important contribution in terms of empirical findings has been research conducted by Lowndes et al (2001a, 2001b) into the consultation practices employed by UK local government. In their comprehensive studies, the authors offer what they term a 'census of local government activity' (2001a:205). The findings on the activities of the Northern Ireland government departments outlined here draw on key aspects cof the Lowndes et al research methodology, utilising their own particular adaptation cof Arnstein's (1969) 'ladder of citizen participation' as a means of analysing the different consultation techniques used by Northern Ireland government departments.

The research presented here represents only a portion of a much larger research project, examining the use of e-consultation techniques in Ireland, both north and south of the border. A key objective of the study was to identify the social context and political implications of electronic forms of consultation and participation in Ireland, north and south. As part of this process, the researchers sought to establish 'baseline' of current public consultation usage. Between 2004 and 2006, online surveys were conducted with central and local government, as well as nongovernmental organisations (NGOs) and community groups. In addition, interviews Gere conducted with a range of relevant actors. ${ }^{2}$ In the case of the Northern Ireland government, all 12 departments submitted responses.

We begin by briefly locating public consultation within the growing literature on governance, where changing pressures and demands on the state (from both outside and within), along with calls for greater democratic transparency and accountability from citizens and interest groups, have positioned public consultation as an important bridge between public administrators and citizens. However, this approach is not without its critics, not least because it omits any consideration of conflict (Davies, 2005), a view that finds resonance with the research presented here.

Any consideration of governance in Northern Ireland must take account of the uniqueness of its constitutional and administrative past, chiefly with respect to the recent conflict and the impact of Direct Rule, and as a prelude to an examination of findings, key aspects in this regard are discussed.The findings themselves suggest that while government departments employed a wide range of consultation techniques (including e-consultation), the preference would seem to be for more traditional techniques such as submission documents or public meetings. Second, while it is indisputable that there exists a high level of enthusiasm for public consultation from 
both consulters and consultees, a number of key challenges are identified. These include the rather limited use of feedback mechanisms by administrators, a need to recognise the challenge of consultation fatigue and problems associated with resource allocation. These issues have become increasingly relevant in recent times with the need to satisfy the legislative requirements of Section 75 - the mainstreaming of equality legislation.

Lastly, this article turns its attention to the contested nature of participation in public consultation. Here, a fundamental disparity exists between public administrators who take a consumerist approach to consulting with citizens, and the citizens themselves who tend to view consultation as an opportunity for democratic empowerment (Cook, 2002). Northern Ireland government departments view public consultation as an excellent way of attaining information for the purposes of satisfying legislative demands, targeting service provision and gaining knowledge of citizens views' on policy issues. Representatives from the community and coluntary sector have indicated in this study that while they view consultation as a means of meaningfully participating in decision making, these expectations have frequently Yed to frustration and disappointment among groups. As a consequence, it is argued here that despite claims from some quarters that the advent of governance marks the emergence of more horizontal modes of decision making, the deployment of consultation in Northern Ireland between 2000 and 2004 was a clear indication that such networks existed very much within hierarchical confines.

\section{Locating governance and public consultation in the Northern Ireland context}

The use of public consultation in Northern Ireland is indicative of a growing disposition towards forms of what is termed 'governance' in states around the world. The exact meaning of term itself has proved somewhat elusive and while it can be argued that 'there is no universally accepted definition of governance', or even a consensus on what set of activities the term encompasses (Jordan et al, 2005: 478), others would claim that a certain orthodoxy has emerged, at least at the theoretical level (Jordan et al, 2005: 477; Davies, 2005:313). One key proponent here is Rhodes (1996, 2000). Employing the term 'governance without government', Rhodes defines this as 'self-organizing, interorganizational networks' that enjoy a relative autonomy - 'Networks are not accountable to the state; they are self-organising' (Rhodes, 2000: 346). The erosion or hollowing out of government's capacity to govern in a transnational environment is cited as a fundamental reason why network governance has become an option for both public administrators and citizens alike (Newman et al, 2004: p 203), where the 'external dependence' of the state on multilateral authorities such as the EU becomes a pertinent feature of policy making (Rhodes, 2000: 351). These new arrangements amount to 'governance-beyond-thestate' (Swyngedouw, 2005: 1991), where the sheer complexity of contemporary administrations 'elude traditional approaches to governing' (Newman et al, 2004: 204). In this context, Dubnick and Meehan (2004: 2) conceptualise governance in Northern Ireland as 'integrative', characterised by the 'uncentering' and 'decentering' of governmental activities. 
Just as the state faces pressure from a sharp increase in the decision-making capacity of transnational networks, Rhodes (2000: 350) points to corresponding pressures 'from below (by marketisation and networks) and sideways (by agencies)'. Marketisation has resulted in the adoption of private sector managerial practices, most notably in the form of New Public Management (NPM) where the 'public-private dichotomy' is now 'essentially obsolete' (Peters and Pierre, 1998: 229). Further, Rhodes (2000: 353) argues that the emergence of governance networks should be viewed as 'a prime example of unintended consequences' of the marketising of the public sector, where cooperation between different organisations and networks becomes the 'organising principle of service delivery'.

Yet, while governance networks are undoubtedly becoming more popular in policy making, this does not necessarily herald the advent of 'governance without government'. While governance may well be about 'autonomous, self-governing networks of actors', its inherent value currently lies in offering a 'new normative theory' rather than providing causal analysis (Stoker, 1998:18) Indeed, evidence from the research presented here suggests that instead of an indication of the emergence of autonomous, self-governing networks, public consultation operates very much 'in the shadow of hierarchy' (Scharpf, 1994: 41), where the government defines the process and manages outcomes. As Davies (2005:312) argues, governance networks care 'designed by government to generate governing capacity' and 'often require governmental discipline to keep them on their political course'. Therefore, instead of replacing centralised government, the findings from this study would suggest that governance is interacting with more established forms of policy making, a relationship that, according to Newman et al (2004: 218) is 'often uncomfortable'.

In addition to the state facing policy and administrative capacity difficulties, the democratic credentials of political institutions and processes are increasingly being called into question. The democratic deficit, explained partly by the imposition of external pressures, has led to a situation where representative democratic structures and processes are experiencing a crisis of legitimacy, facing growing demands 'for 'a more transparent, and permeable, policy process' (Bishop and Davis, 2002: 15). In support of this view, Pierre (2006: 1) cites evidence from Denmark and Norway where there is 'declining support for traditional structures' and where citizens 'look favourably at more participatory forms of political input'. This echoes Bishop and Davis' (2002: 14) assertion that 'evidence from across the OECD [Organisation for Economic and Co-operation Development] shows rising demands for citizen participation in policy choices'. Yet, it must also be pointed out that these findings are far from conclusive and, if anything, are an indication of the contentious nature of many of the claims made in relation to governance. For instance, Stoker (1998: 18) cites evidence from research into local governance that strongly suggests that the public actively prefer 'organisation and control of local services to be in the hands of an elected council'.

Nevertheless, the problems associated with a democratic deficit are particularly important in the context of Northern Ireland, characterised as it was until recently by conflict and Direct Rule from London. In 1972, with the conflict seemingly spiralling out of control, the British government imposed what was originally conceived as a temporary period of Direct Rule (which in fact lasted until 1999), where the powers of the Northern Ireland Executive and Parliament at Stormont 
were suspended.The job of governing Northern Ireland now fell under the auspice of the Northern Ireland Office (NIO), headed by the Secretary of State for Northern Ireland, a British Cabinet minister. What this effectively meant, according to senior Northern Ireland civil servants, was that the senior civil service played 'a much stronger role in policy formulation and public presentation', while at the same time ministers adopted a 'hands-off approach', characterised by 'ignorance and lack of interest' (Carmichael and Osborne, 2003: 207). Public administration became, according to Knox (1998: 152), the remit of an increasing number of 'quangos and unelected bodies', in a system characterised by a lack of local democracy or public accountability.

As Northern Ireland moved out of conflict and into the peace process, the issue of this democratic deficit was addressed in the 1998 'Good Friday Agreement' (GFA) or 'Belfast Agreement', where 'devolution was offered as a part of a wider process of democratisation' (Tonge, 2005: 54). The provisions of the GFA effectively meant an end to Direct Rule by establishing an elected assembly and a ministerial Cabinet and Executive, both of which were based on principles of power sharing. Yet, given the sometimes belligerent environment that cross-community politics operated in, it is unsurprising that the embryonic peace process was beset with setbacks, most notably in 2002 and 2005, where the institutions of the GFA were suspended. However, in 2007, a new Executive comprising of Sinn Fein and the Democratic Inionist Party (DUP) was elected and has, up to now, brought a certain degree of stability to political institutions and processes.

One important legacy of the democratic deficit during the period of conflict and Firect Rule was the emergence of a significantly large and vibrant community and ovoluntary sector (McCall and Williamson, 2001:371). Its growth and importance can be explained at least in part by 'a general dissatisfaction with what many perceived tô be sterile local politics' during this time (Carmichael and Osborne, 2003: 209). Aughey (2005: 76) points out that the sheer size of this sector is 'striking', numbering some 5,000 voluntary and community groups, employing some 35,000 staff and generating a gross income of $£ 514$ million. Since 1998, it has been directly involved in governance in different capacities, for instance through the Civic Forum and through sometimes exhaustive consultations on equality in legislation under Section 75 of the 1998 Belfast Act.

The importance of horizontal modes of governance becoming a prominent feature on the political landscape in post-conflict Northern Ireland can be seen to indicate a refreshingly new way of 'doing business' between the two divided communities. According to a representative from the Equality Commission for Northern Ireland interviewed for this research, the political settlement in Northern Ireland in 1998 was based on "consensus and discussion and dialogue at every stage, right up to Cabinet level". However, while Dubnick and Meehan (2004) make a similar claim that governance in the Northern Ireland context is 'unusually participatory by international standards' (2004: 7), they acknowledge that the constitutional arrangements enshrined in the GFA remain 'consistent with the vertical chain of command model found in liberal democracies' (2004: 6) Also, while it can be argued that the institutional arrangements emanating from the GFA are based on a consensual model of governance, they are fundamentally 'elitist, consociational, top-down models of power sharing', contrasting with the 'idealised democratic, 
bottom-up alternatives' favoured by civil society (Aughey, 2005: 76). In other words, the consociational approach that lies at the core of the Northern Ireland government relies more on an elite political consensus - based on a so-called 'least best option' (Tonge, 2005: 37), rather than focusing on meaningful participatory forms of governance.

The fortunes of the Civic Forum illustrate this criticism. Unveiled as an intregal part of the 1998 Agreement that would allow civil society to have an input into policy making through consultation, its lack of 'democratic legitimacy' - chiefly because members were nominated by special interest groups, including the First Minister and Deputy First Minister - ensured that the Forum 'acquired the reputation of being an expansive, somewhat expensive, filtered gathering of special interests' (Tonge, 2005: 205) and little else. While civil society might well be invited to participate in processes surrounding policy making, it would appear that this participation would stop well short of involvement in any final decision making.

It is unsurprising, therefore, that what constitutes 'participation' in consultation is a key point of contention between theorists, public administrators and citizens alike. Bishop and Davis' (2002) comprehensive review of various models for evaluating participation in governance draws on the fundamental differences in perspectives between administrators and participants. For instance, the authors argue that the models offered by Arnstein (1969) and Pateman (1970) evaluate different modes of governance in terms of levels of involvement of participants, as well as their ability to influence policy outcomes. In contrast, alternative framings offered by Thomas (1990) and to an extent by Shand and Arnberg (1996) conceptualise participation from the viewpoint of policy makers, where the type of participation is in proportion to the policy goal or the policy choices on offer. From the latter perspective, the pilblic are sometimes conceptualised as 'passive consumers; childlike and clamorous Paiblic; and/or lacking skills, capacities or trust' (Newman et al, 2004: 210) This consumerist framing of citizen participation suggests that policy makers view governance primarily as means of driving more efficient policy and service delivery, rather than enabling wider and deeper citizen involvement in decision making, a position that has resonance with the findings of this current study.

The problematic nature of participation is identified in Lowndes et al's (2001b) study of citizens' perspectives of public participation with local government in the UK. Here, a key finding is a perception that local councils were 'unresponsive to public concerns' and that this perception ultimately acted as a strong deterrent in participating in such processes (Lowndes et al, 2001b: 452). The study also identifies the key issue of 'raising public expectations through participation' (2001b: 453), again, a feature that is mirrored in the research presented here. Tracing the recent history of UK third sector involvement in the policy-making environment, Taylor and Warburton (2003: 327) show that expectations were indeed raised with the arrival of the New Labour government in 1997, where a 'compact' formally acknowledged 'the right of the sector "to campaign, to comment on Government policy and to challenge that policy, irrespective of any funding relationship that might exist", Despite this however, Taylor and Warburton's own research concluded that 'many barriers to greater (and more effective) third sector policy engagement remain and that greater opportunities to voice issues have not necessarily led to greater policy influence or to policy change' (2003: 328). 
Lastly, given that fundamental differences exist between different parties on issues of participation, the role of government and the autonomy of networks, any examination of governance and consultation must include a consideration of conflict and the exercise of power. While this might seem self-evident, Davies (2005: 321) suggests that it is a dimension that is given limited scope in many existing conceptualisations of governance - ' $[\mathrm{t}]$ he point is not that conflict has been ignored, but that there has been little or no analytical reflection about the implications of conflict'. A degree of conflict is almost inevitable given the different expectations of service providers and citizens, where on the one hand, consultation can be framed as primarily a means of eliciting user views on service provision by administrators - the 'consumerist' model of citizenship - while on the other hand, it is frequently viewed by citizens as a means of directly impacting on policy outcomes - the 'empowerment approach' to citizenship (Cook, 2002: 524-5). Additionally, while Bishop and Davis (2002: 22) conceptualise consultation as an agreed arrangement between participants and government, where it is acknowledged that 'governments will decide', it may not be too cynical to suggest that policy-makers are only too happy to encourage the perception that citizens are in some way directly involved in decision-making through consultations, giving an opportunity 'to portray themselves as modern, caring and responsive' (Pratchett, 1999: 618). In this respect, public consultation can be used a means of legitimising difficult and sometimes controversial policy decisions (Murray, 2006: 461).

\section{The use of consultation techniques by Northern Ireland government departments}

This research sought to establish the variety and frequency of consultation techniques that had been utilised by different government departments. The researchers listed 26 different techniques - employing the same listing used by Lowndes et al (2001a) in their study of UK local government, where they adopted the various 'rungs' of 'Arnstein's (1969) 'ladder of citizen participation' (Lowndes et al, 2001a:207), in order to analyse different forms of citizen participation. Because one of the objectives of the study was to ascertain the usage of e-consultation, eight such techniques were listed separately from the 18 more traditional modes of public consultation. The key finding, shown in Figure 1, is that more traditional modes of consultation are the most commonly deployed by government departments, namely the use of 'consultation documents' (used by all 12 departments) and 'public meetings' (8 departments).

While Cook (2002:517) argues that such traditional modes are viewed by officials as 'tokenistic, unrepresentative and not engaging', it is significant that the third most popularly used mode - 'focus groups' (employed by seven departments) - was identified by Lowndes et al (2001a) as deliberative in nature, possibly reflecting the importance of a consensual approach to governance in Northern Ireland in general.

Thirteen different techniques were used, indicating some diversity of strategies employed in order to consult with the public. While the use of focus groups was relatively popular among departments, other deliberative techniques fared less well, with the following not used at all - referendums, community plans, citizen's panels, co-option/committee involvement and visioning exercises. 


\section{Figure I:Traditional consultation techniques used by Northern Ireland government departments}

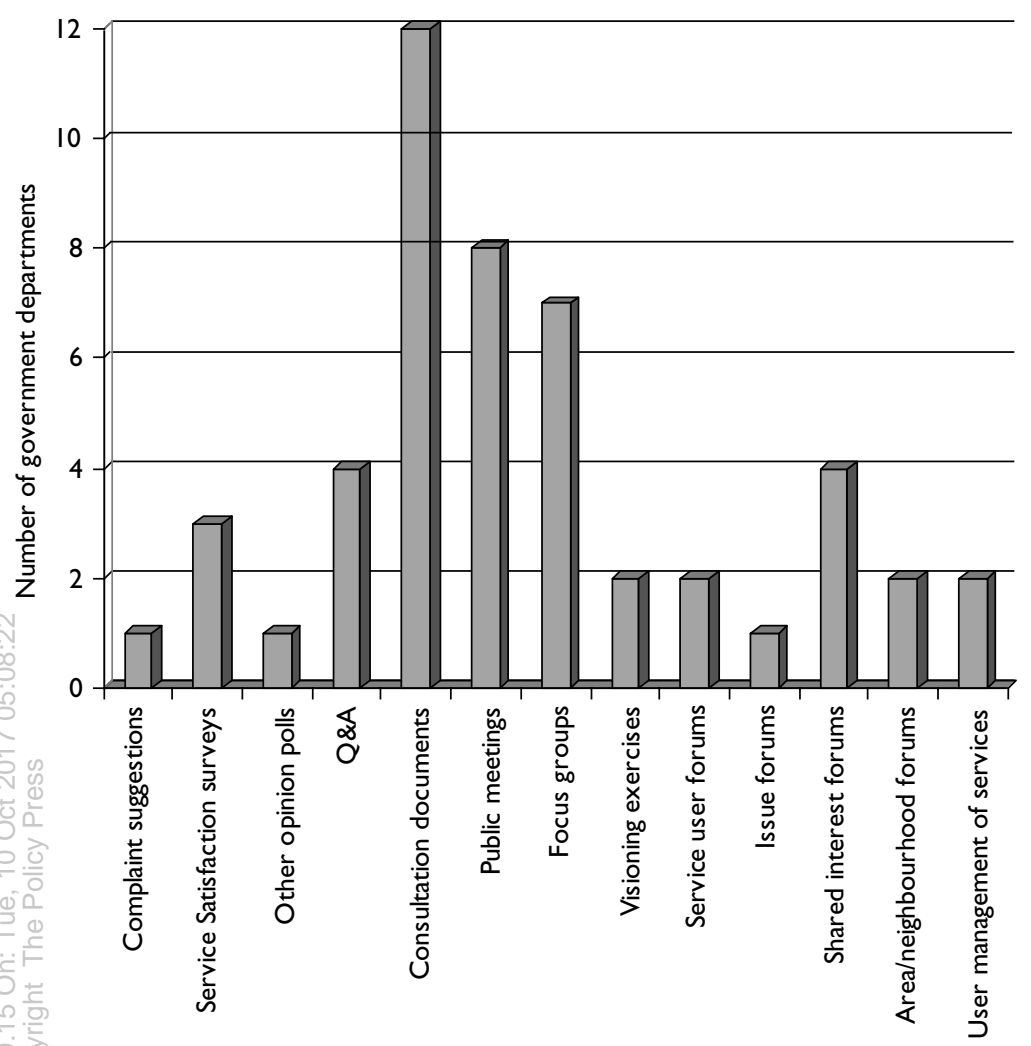

Both local and central government in Northern Ireland have long recognised the potential of e-technologies in governance. ${ }^{3}$ Moreover, Morison and Newman (2001: 188) identify the use of electronic techniques as an innovation that offers the possibility of creating new spaces for democratic participation, immersing governance networks in an 'active democracy', where 'citizens are involved as much as is practical'. In addition, McCall and Williamson (2001:370) argue that the 'information revolution has increased the transparency of governance, stimulating the interest of citizens in its process'. With this in mind, the use of 'e-consultation' was somewhat limited. Only six departments employed electronic techniques, and out of a possible list of eight different techniques listed by researchers, only three were used in the period 2000-03. The e-consultation techniques used were 'communities of interest emailing lists', 'documentary/policy comment websites' and 'online polls and surveys'. ${ }^{4}$ Interestingly, one respondent claimed that their department did not have the software to engage in e-consultation.

\section{Engaging with the public: government aims and objectives}

The single most important reason cited for initiating public consultations was the need to meet statutory requirements, with $75 \%$ of respondents identifying this. The 
two key components of this were the need to meet equality legislation, identified by $66.7 \%$ of respondents, and the need to meet EU requirements, identified by $58.3 \%$ of respondents. However, one government respondent was keen to point out that consultation was "an essential element of good policy making and of achieving 'buyin'. It is within this context that specific consultation initiatives must take place".

Figure 2 shows that the need to improve service quality was seen as 'very important' by $66.7 \%$ of respondents, while developing 'best practice' initiatives was viewed as 'very important' by $41.7 \%$ and 'important' by $41.7 \%$ of respondents respectively. Lastly, and significantly, the role of the citizen in consultation was identified as a factor in initiating consultation, with $58.3 \%$ of respondents identifying the need to encourage citizen participation in decision making as 'very important'. However, as is discussed below, the exact nature of this participation appears largely unclear from the point of view of many citizens.

Figure 2:The main purposes of engaging in public consultation

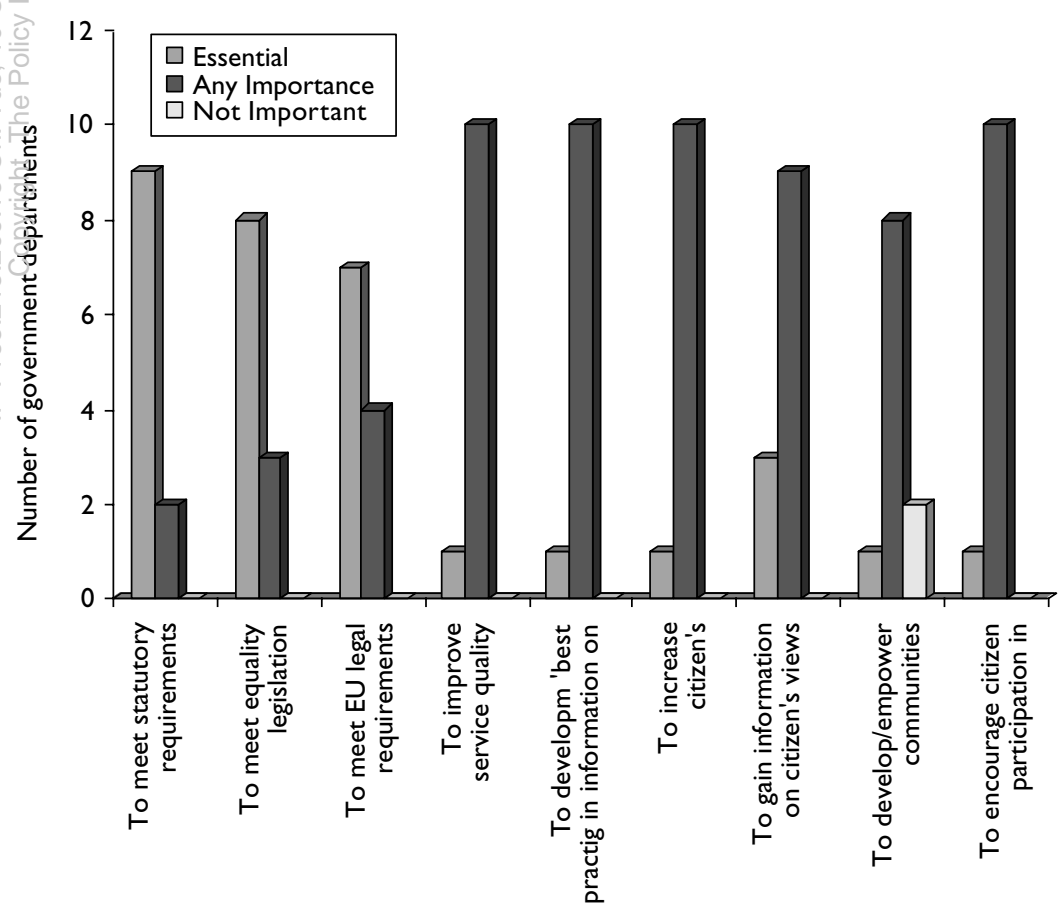




\section{Public consultation in context: benefits, challenges and the impact of Section 75}

\section{Benefits}

Corresponding closely with the findings of the Lowndes et al (2001a) study of public consultation practices in UK local government, the key benefit to be derived from engaging in consultation for Northern Ireland government departments was 'better policy making', with $91.7 \%$ of respondents identifying this. Closely related to this was the issue of 'better decision making on specific points', with $75 \%$ seeing this as an 'important' benefit. However, while 'improvement in services' was identified above as a key initiator of consultation, it scored relatively low here, with only $25 \%$ identifying this as a benefit. These findings can be seen in Figure 3.

\section{Figure 3:The perceived benefits for central government in entering into consultation processes}

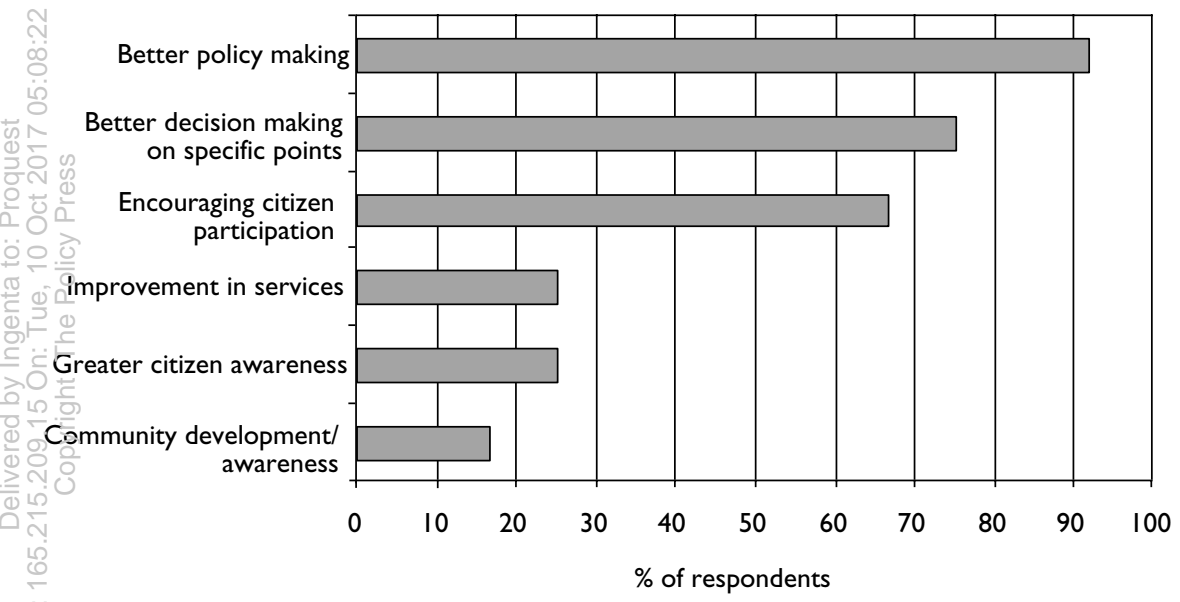

Respondents also identified 'encouraging citizen participation in decision making' as a key benefit in using consultation. Defining the quality of this participation was a key issue and for many government respondents public participation should be concentrated on policy processes rather than outcomes. As one government department official put it, "generally it helps improve decision and policy making, and achieves greater ‘buy-in’ from key stakeholders ... [it has] some impact, but fairly minimal". This issue is discussed in more detail below.

In general, government respondents viewed consultation as a way of coming to "more informed decisions made by government". More specifically, one respondent asserted that "consultation initiatives provided a useful means of reaching different sections of the community through the medium that suited their needs", while another commented that consultation ensured that "equality of opportunity is considered in decision making and mitigations offered where potential negative impacts have been identified". 


\section{Challenges}

Northern Ireland government departments did not identify any factors that could be described as significantly problematic in the running of public consultation processes. Of a list of five possible factors, only 'lack of public interest' was identified as in any way problematic, albeit not in a significant way, followed by 'lack of resources' and 'lack of time'. These findings are represented in Figure 4.

\section{Figure 4: Challenges in initiating public consultation}

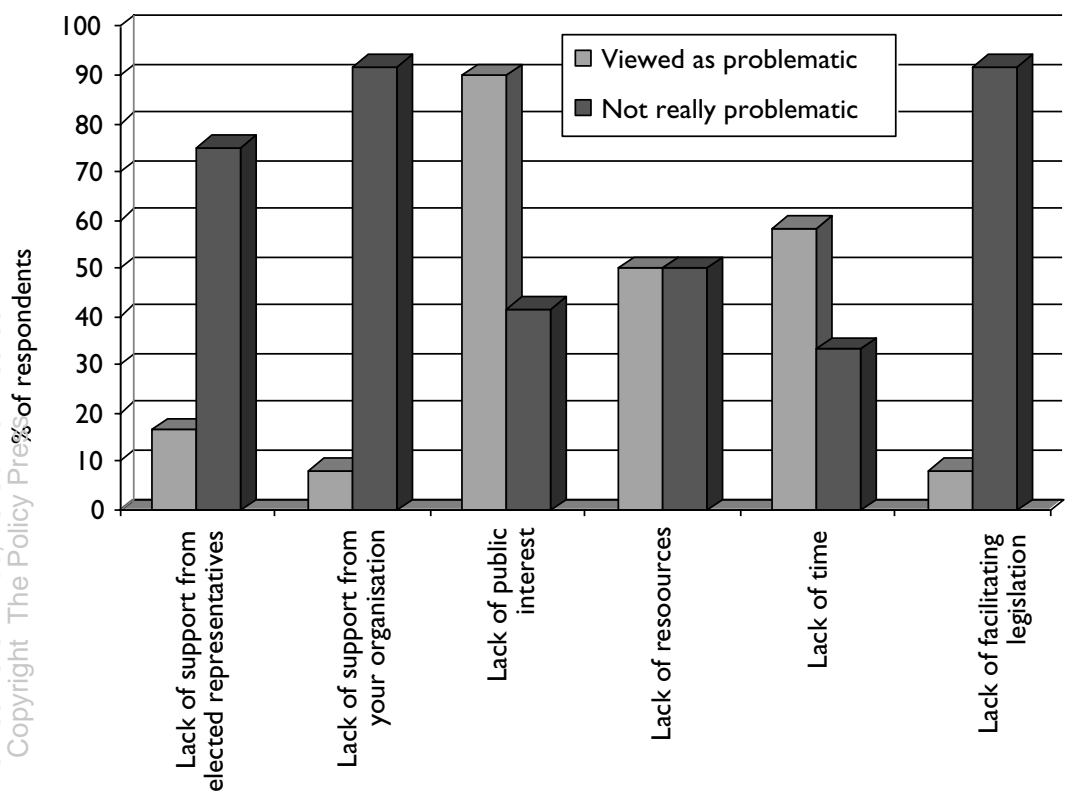

Respondents were invited to list any other factors that contributed to the challenge facing public administrators. Here there was a recognition that both the use of certain techniques and the sheer quantity of consultations had contributed to consultation fatigue among participants. One respondent identified the use of consultation documents that "tend to contain a large amount of reading material, which seems to put a lot of people off responding". Written submissions also challenged administrators because, according to one respondent, "dealing with large volumes of written consultation responses can be time-consuming and difficult to manage/ analyse". This acknowledgement that consultation fatigue was a salient feature of current practice was reflected when respondents were asked to evaluate certain factors that contribute to this fatigue (Table 1). Here, three issues - 'the public are asked to engage in too many consultations' (50\%), 'current consultation techniques are too time-consuming' (66.7\%) and 'a public perception that consultation does not influence policy' $(83.3 \%)$ - were all identified as being 'difficult' to a significant degree. 
Table I:The challenge of 'consultation fatigue' (\%)

\begin{tabular}{|l|c|c|c|c|}
\hline & $\begin{array}{c}\text { Very } \\
\text { difficult }\end{array}$ & Difficult & $\begin{array}{c}\text { Only slightly } \\
\text { difficult }\end{array}$ & $\begin{array}{c}\text { Not difficult } \\
\text { at all }\end{array}$ \\
\hline $\begin{array}{l}\text { The public are asked to engage in } \\
\text { too many consultation processes }\end{array}$ & 0 & 50 & 16.7 & 0 \\
\hline $\begin{array}{l}\text { Current consultation techniques are } \\
\text { too time-consuming }\end{array}$ & 8.3 & 66.7 & 16.7 & 0 \\
\hline $\begin{array}{l}\text { A public perception that consultation } \\
\text { does not influence policy }\end{array}$ & 0 & 83.3 & 0 & 8.3 \\
\hline $\begin{array}{l}\text { The public are repeatedly asked the } \\
\text { same questions }\end{array}$ & 0 & 16.7 & 8.3 & 33.3 \\
\hline
\end{tabular}

These views were confirmed by representatives from the community and voluntary sector. Specific issues identified here were the volume of consultations - one respondent estimated that their organisation dealt with in the region of 500 processes per year. Another issue was the lack of effective targeting of consultations, where organisations are asked to submit views on policy proposals that have little or no impact on their own work. One commented: "we've been badly consulted about the wrong things".

\section{The impact of Section 75}

While the issue of consultation fatigue was identified as a challenge in general terms, the introduction of Section 75 legislative requirements in Northern Ireland has axacerbated this to a significant degree. Section 75 of the 1998 Northern Ireland Act is designed to ensure that public policy safeguard's equality of opportunity on the basis of nine designated areas, including religion, political orientation, gender, race, ethnicity and disability. The idea of equality proofing legislation is not unique to Northern Ireland, as it has been seen as an increasingly important part of 'good' governance internationally (Osborne, 2003: 355). According to one representative from the Northern Ireland government, Section 75 was now "an accepted part of the policy development process". It was also a key initiator of public consultation, with one respondent stating:" "The key drivers for consultation for NI departments relate to statutory obligations arising out of Section 75 and the requirement to consult on draft legislation. It is also seen as part of good policy making generally". Equally, the Equality Commission for Northern Ireland, the statutory body that oversees the implementation of equality legislation, sees consultation as an integral part of policy making not least because it makes policy making 'more transparent and accountable' (Equality Commission for Northern Ireland, 2002: 2).

However, the requirement to consult on Section 75 has created its own problems, where the sheer volume of consultations impacts on response rates. One public administrator commented: "Some members of the public feel that they are being 'consulted to death' and consultations for different things frequently happen at one time". The issue of consultation fatigue was also identified as a challenge by the Equality Commission (Equality Commission for Northern Ireland, 2002: 19) The representative from the Equality Commission interviewed conceded that there 
were outstanding issues in relation to Section 75 and consultation fatigue: "I think that's a learning process for us you know ... to see which methods work and which methods don't work". Moreover, Osborne (2003: 349) found that the initial wave of equality schemes proved problematic for public authorities in terms of increased pressure on budgets and resources.

Again, these views were largely echoed by citizens and members of community and voluntary organisations. A representative from the community and voluntary sector identified Section 75 requirements as a 'big driver' of public consultation. However, this has sometimes had a negative effect on organisations: "it is a drain on resources, it's a drain on policy capacity". This expending of resources can lead to the 'isolation' of some smaller groups who simply do not possess the resources to engage with the plethora of consultations to organisations, sometimes on a weekly basis.

While acknowledging that consultation fatigue was an important issue, some members of the community and voluntary sector showed a distinct reluctance to employ the term 'fatigue' because of a fear that it would be mistaken by public administrators as a reluctance to engage in consultation processes. One commented: "I suppose some of us around this table ... would be nervous about the term 'consultation fatigue', because the risk is that it is then used as 'lets not consult you",.

\section{From hierarchy to heterarchy? The contested nature of participation in public consultation}

While 'encouraging citizen participation in decision making' was identified as a key benefit for utilising consultation, there was a general consensus on the part of government respondents that this public participation did not necessarily mean influencing policy decisions and outcomes. One government official commented:

"[B]eing part of the consultation process does not mean you're part of the decision-making process ... because at the end of the day, everybody in consultation will express a slightly different opinion and somebody at the end of the day has to make a decision and that person is the minister ... and I think sometimes there are unrealistic expectations ... and part of what consulters have to do is to manage expectations."

Instead, public consultation is viewed primarily as a means of 'increasing the information or range of perspectives available to decision makers' (Catt and Murphy, 2003: 408) and critically, the extent of public involvement in public management is determined by the administrator's assessment of 'the relative needs for quality or acceptability in a decision' (Thomas, 1990: 436). Here, provisions made under Section 75 for the equality proofing of legislation would be particularly applicable. Moreover, the notion of 'managing expectations' or maintaining boundaries around decision making suggests a public participation model based more on 'steering', a salient feature of both governance and New Public Management, where the key objective is 'setting objectives and defining goals' (Peters and Pierre, 1998: 231). What emerges is what Cook (2002: 526) refers to as the 'consumerist' model of participation, where citizens are afforded certain rights 'to information, complaints 
and redress', but crucially, 'these "rights" are not based on the ability to affect policy outcomes'.

Divergences between the public and government over the extent of participation in consultation mechanisms became evident when the views of citizens and representatives from the community and voluntary sector were examined as part of this study. Frequently, they expressed the view that while public consultations offered opportunities for involvement in policy making, the actual extent of this involvement was frequently limited. While participants' expectations may be whetted by the prospect of 'evidence-based' or even an 'empowerment' approach to policy making (Cook, 2002:526) based on the consultation process, the reality was distinctly underwhelming for some. One representative from the community and voluntary sector commented: "you're invited into a room, you've been brought onboard, but ... the actual outcome, the key decision, has actually been made and there is a sense of going through the motions". Moreover, others thought that public administrators only entered into processes on the basis of satisfying legal requirements, rather than to genuinely encourage or facilitate democratic participation. One community and voluntary sector respondent stated: "it's the attitude of the people that are doing the consulting ... they're doing it because they have to and people know that"; while another thought that consultation was used by public administrators as a "legitimising ctool' for certain, difficult policy decisions. This frustration at participation as an empty ritual' (Arnstein, 1969: 216) was tempered with the acknowledgement that non-participation was not an option for many in the community and voluntary sector. For instance, one respondent offered the view that many in the sector have been effectively coerced into participating in public consultation: "they pull in the community sector, the voluntary sector and ... you're working on a basis of "you owe us".

One important issue directly related to participation concerns the provision of feedback mechanisms in order for citizens to evaluate consultation processes, or as Cook (2002: 528) asserts, "closing the feedback loop" is essential to ensure the validity and sustainability of any consultation process'.Yet, this research showed that of the 12 government departments surveyed, only six provided such mechanisms. A concern frequently raised by citizens and community and voluntary organisations was that a high degree of resources are expended in processes that subsequently yield little in the way of influencing policy outcomes. This lends a certain credence to the view expressed by some in the community and voluntary sector that, on occasion, it would appear that key decisions are made by government departments regardless of consultations and that any submissions made during the process are effectively ignored. One representative from the community and voluntary sector claimed that there was:

“... almost a statutory requirement to send out information and to have consultation carried out almost at a functionary level. We don't see any return in terms of old people's strategy or youth strategy. You ... can't actually find within their documents your information that was provided." 
The deployment of feedback mechanisms obviously impacts on the ability of government to respond to a wide range of public opinion, which Pratchett (1999: 629) argues is fundamental to public participation in policy making. In the context of consultation, feedback is critical in building up a relationship of trust between government and citizens. According to one representative from the community and voluntary sector, adequate feedback processes are vital in order to build up trust: "I think that's what we need to see, otherwise we just say 'well, you're [public administrators] doing this because you have to do it and it's set down in legislation that you have to consult". 5 This issue is mirrored by the findings of Lowndes et al (2001b: 453), where 'better feedback on outcomes - whether positive or negative, "soft" or "hard" - are necessary to challenge citizens' cynicism and their resultant reluctance to participate'.

The fissures between the consumerist and empowerment approaches to participation are palpable in this study. On the one hand, representatives from Northern Ireland government departments indicated their belief that participation in public consultation does not automatically equate with influencing final outcomes. These views of participation in consultation correlate closely to Pratchett's (1999: 618 ) description of consultation in the UK in the 1980s where citizens were "narrowly defined' as 'consumers of services' and that consultation enabled public cadministrators to target services and open vital channels of communication with citizens. For their part, citizens repeatedly complain that their views are not listened to and that they have little or nothing to show for engaging valuable time and resources into what can be a lengthy and sometimes futile process.

Bearing in mind that both government officials and community and voluntary sector representatives agree that the final instance of decision making remains protected from the public, it is hard to escape the conclusion that despite the adaption of more inclusive mechanisms and language in public policy making in Northern Ireland, the practice of public consultation does not signal a significantly new approach of 'doing business' on the part of public administrators. It will be recalled that Davies (2005) asserted that many existing conceptualisations of governance 气effectively ignore issues of conflict and power. Yet, power and, albeit latent, conflict shape the core issue of participation. It is a view borne out by respondents who indicate, at the very least, a tacit awareness of the asymmetry of power among those engaged in consultation processes. This awareness has much stronger resonance in the disappointment expressed by community and voluntary sector representatives in being unable to influence decisions, or more alarmingly, in their fears in complaining of consultation fatigue or contemplating non-participation in the consultation processes.

Arnstein's (1969: 216) 'ladder of citizen participation' is premised on the idea of a redistribution of power from administrator to citizen where 'citizen participation is a categorical term for citizen power'. Such a scenario would appear to be highly implausible or even possibly undesirable in the context of Northern Ireland. Yet, without any redistribution of power - other than the ability to participate in a process as opposed to being involved in final outcomes - severally negates any claims of a shift away from the shadow of hierarchy towards more participatory decision making. As a consequence, the consultation practices surveyed here largely 
signal a continuation of hierarchical administration, rather than the emergence of a heterarchy or new horizontal mode of governance.

\section{Conclusion}

This research shows that public consultation is firmly embedded in the day-to-day workings of the Northern Ireland government. As one representative from the Northern Ireland government put it,"consultation should be a permanent dialogue of multilateral conversation with our many key stakeholders". Findings here suggest that government departments still rely to a large extent on more traditional forms of the consultation, particularly the use of consultation documents and public meetings. This reliance on consultation documents, particularly in relation to Section 75 initiatives, has led to a 'bureaucratic paper trail' and contributes to the consultation fatigue felt by many in the community and voluntary sector (Osborne, 20034: 350). Both consulters and consultees identified the issue of the pressure on resources and overall consultation fatigue as two significant challenges. The advent Of Section 75 legislative requirements has brought these concerns to the forefront, with a representative from the Equality Commission acknowledging that consulting on equality proofing legislation is a learning process in the development of a more Eeffective and strategic approach to public consultation.

Equally, the techniques preferred by government departments largely reflect the stated objectives for public consultation, where the priority is improving service provision and the better targeting of policy. The more traditional methods of consultation emphasise information gathering from citizens and interest groups rather than deliberative modes of involvement in policy making. This leads to the key issue of what should constitute participation when it comes to public consultation. Findings here suggest that public administrators in the Northern Ireland government favour a consumerist rather than an empowerment model of citizen participation. While public consultation is viewed as an important component of governance, its increasing use should not, as Lowndes et al (2001: 215) suggest, be taken as an indication of 'democratic enhancement'.

Moreover, this approach to consultation gives credence to the view that governance processes are situated within a largely centralised hierarchy, rather than indicating any significant emergence of 'governance without government'. For their part, citizens engaging with the government through consultation do so enthusiastically, although some evidence of coercion emerged in this study. Concerns were voiced over the extent to which the government is willing to enter into a meaningful dialogue with organisations and individuals, and to what degree consultation is merely paying 'lip service' to the idea of involving citizens in policy making. This concern was not helped by the fact that only half of government departments offered feedback and evaluation mechanisms in the time period of this research. Despite this and other acknowledgements that consultation between the years 2000 and 2004 was essentially a 'work in progress', some basic questions of power remained largely unaddressed by government departments but were fundamental for the involvement of citizens and the community and voluntary sector. This is salient in the findings presented here and, we suggest, should form the basis for important future research in this field. 


\section{Notes}

${ }^{1}$ This article makes reference to the notable exceptions of the work of Lowndes et al (2001a, 2001b), Taylor and Warburton (2003), Newman et al (2004) and Jordan et al (2005).

${ }^{2}$ In addition to online surveys with central and local government and the community and voluntary sector in Northern Ireland and the Republic of Ireland, interviews were conducted with representatives from central government, local government, the community and voluntary sector and non-governmental organisations - both North and South of the border. In addition, focus groups were conducted with representatives from the community and voluntary sector north and south of the border.

${ }^{3}$ See E-Consultation Research Project (2006: 12) for more discussion on this point.

${ }^{4}$ Five other e-techniques listed in the survey were not used at all - online conferences, live chat events, online petitions, online submissions and online focus groups.

This issue is recognised by the Equality Commission for Northern Ireland (2004).

\section{Acknowledgements}

The research presented here is from a research project entitled ' $E$-consultation: evaluating appropriate technologies and processes for citizens' participation in public policy'. The project was funded by the European Union's Peace \& Reconciliation Fund and involved a research team from NUI Maynooth, Letterkenny IT and Queens University Belfast. The authors would particularly like to thank the National Institute for Regional and Spatial Analysis (NIRSA), the Higher Education Authority (HEA) and Morgan O'Brien (NUI Maynooth) for assistance in the research project.

\section{References}

Andersen, S. and Loftager, J. (2005) 'Deliberative democratic governance', Paper delivered at the NOPSA conference, Reykjavik, accessed at http://registration. yourhost.is/nopsa2005/papers/Deliberative $\% 20$ democratic $\% 20$ governance, $\% 2$ ONOPSA.pdf

Arnstein, S. (1969) 'A ladder of citizen participation', Journal of the American Planning Association, vol 35, no 4: 216-24.

Aughey,A. (2005) The politics of Northern Ireland: Beyond the Belfast Agreement, London: Routledge.

Bishop, P. and Davis, G. (2002) 'Mapping public participation in policy choices', Australian Journal of Public Policy, vol 61, no 1:14-29.

Carmichael, P. and Osborne, R. (2003) 'The Northern Ireland Civil Service under Direct Rule and devolution', International Review of Administrative Sciences, vol 69: 205-17.

Catt, H. and Murphy, M. (2003) 'What voice for the people? Categorising methods of public consultation', Australian Journal of Political Science, vol 38, no 3: 407-21. 
Cook, D. (2002) 'Consultation for a change? Engaging users and communities in the policy process', Social Policy and Administration, vol 36, no 5: 516-31.

Davies, J. (2005) 'Local governance and the dialectics of hierarchy, market and network', Policy Studies, vol 26, nos 3/4:311-35.

Dubnick, M. and Meehan, E. (2004) Integrative governance in Northern Ireland, Working Paper QU/GOV/16/2004, Belfast: Institute of Governance, Public Policy and Social Research, Queen's University Belfast.

E-Consultation Research Project (2006) E-consultation: Evaluating appropriate technologies and processes for citizens' participation in public policy, Available at www. nuim.ie/nirsa/econsult/index.html

Equality Commission for Northern Ireland (2002) Summary report on the implementation of the Section 75 Equality and Good Relations Duties by Public Authorities, Accessed at www.equaltyni.org

Equality Commission for Northern Ireland (2004) Equality Commission's response to the review of public administration, April 2004, Accessed at www.equaltyni.org

Jordan, A., Wurzel, R. and Zito,A.. (2005) 'The rise of "new" policy instruments in comparative perspective: has governance eclipsed government?', Political Studies, vol 53: 477-96.

Knox, C. (1998) 'The European model of service delivery: a partnership approach in Northern Ireland', Public Administration and Development, vol 18: 151-68.

L.owndes,V., Pratchett, L. and Stoker, G. (2001a) 'Trends in public participation: part 1 - local government perspectives', Public Administration, vol 79, no 1:205-22.

Lowndes,V., Pratchett, L. and Stoker, G. (2001b) 'Trends in public participation: part 2 - citizens' perspectives', Public Administration, vol 79, no 2: 445-55.

$\bar{M}$ cCall, C. and Williamson, A. (2001) 'Governance and democracy in Northern Ireland: The role of the voluntary and community sector after the Agreement', Governance: An International Journal of Policy and Administration, vol 14, no 3: 363-83.

Morison, J. and Newman, D. (2001) 'On-line citizenship: consultation and participation in New Labour's Britain and beyond', International Review of Law = Computers and Technology, vol 15, no 2:171-94.

Murray, M. (2006) 'Multi-level 'partnership' and Irish waste management: the politics of municipal incineration', Economic and Social Review, vol 37, no 3: 447-67.

Newman, J., Barnes, M., Sullivan, H. and Knops, A. (2004) 'Public participation and collaborative governance', Journal of Social Policy, vol 33, no 2: 203-23.

Osborne, R.D. (2003) 'Progressing the equality agenda in Northern Ireland', Journal of Social Policy, vol 32, no 3: 339-60.

Pateman, C. (1970) Participation and democratic theory, Cambridge: Cambridge University Press.

Peters, B.G. and Pierre, J. (1998) 'Governance without government? Rethinking public administration', Journal of Public Administration Research and Theory, vol 8, no 2: 223-43.

Pierre, J. (2006) 'Democratic government and the challenge of governance: a research program presented to the Swedish Science Council', Gothenburg: Department of Political Science, University of Gothenburg (www.pol.gu.se/file/Document/ Jon $\% 20$ Pierre $\% 20$ Democratic $\% 20$ Government $\% 20$ and $\% 20$ the $\% 20$ Challenge $\% 2$ 0of\%20Governance.pdf). 
Pratchett, L. (1999) 'New fashions in public participation: towards a greater democracy?', Parliamentary Affairs, vol 52, no 4: 616-33.

Rhodes, R. (1996) 'The new governance: governing without government', Political Studies, vol 44: 652-67.

Rhodes, R. (2000) 'The governance narrative: key findings and lessons for the ESRC's Whitehall Programme’, Public Administration, vol 78, no 2: 345-63.

Scharpf, F.W. (1994) 'Games real actors could play: positive and negative coordination in embedded negotiations', Journal of Theoretical Politics, vol 6, no 1:27-53.

Shand, D. and Arnberg, M. (1996) 'Background paper' in responsive government: service quality initiatives, Paris : Organisation for Economic Cooperation and Development

Smismans, S. (2006) New modes of governance and the participatory myth, European Governance Papers (EUROGOV) no. N-06-01, (www.connex-network.org/ eurogov/pdf/egp-newgov-N-06-01.pdf).

Stoker, G. (1998) 'Governance as theory: five propositions', International Social Science Journal, vol 50, no 155: 17-28.

Swyngedouw, E. (2005) 'Governance innovation and the citizen: the Janus face of governance-beyond-the-state', Urban Studies, vol 42, no 11: 1991-2006.

Taylor, M. and Warburton, D. (2003) 'Legitimacy and the role of UK third sector organisations in the policy process', Voluntas: International Journal of Voluntary and Nonprofit Organisations, vol 14, no 3: 321-38.

Thomas, J. (1990) 'Public involvement in public management: adapting and testing 'a borrowed theory', Public Administration Review, vol 50, no 4: 435-45.

Tonge, J. (2005) The new Northern Ireland politics?, Basingstoke: Palgrave.

Michael Murray, Department of Adult and Community Education, NUI Maynooth, Co. Kildare, Ireland, michael.j.murray@may.ie

G. Honor Fagan, Department of Sociology, NUI Maynooth, Co. Kildare, Ireland Paul McCusker, School of Business Studies, Letterkenny Institute of Technology,

Co. Donegal, Ireland 
Reproduced with permission of copyright owner. Further reproduction prohibited without permission. 